\title{
Model pembelajaran process oriented guided inquiry learning (POGIL): Peningkatan disposisi matematika dan self-confidence mahasiswa tadris matematika
}

\author{
Elfi Rahmadhani \\ Jurusan Tadris Matematika, STAIN Gajah Putih Takengon Aceh Tengah. \\ Jalan Yos Sudarso/A. Dimot No. 10 Takengon, Aceh Tengah, Nangroe Aceh Darussalam, Indonesia. \\ * Corresponding Author. E-mail: elfirahmadhani88@gmail.com \\ Received: 27 August 2018; Revised: 26 October 2018; Accepted: 4 November 2018
}

\begin{abstract}
Abstrak
Penelitian ini bertujuan untuk mengetahui peningkatan disposisi matematika dan self-confidence mahasiswa dengan menerapkan model pembelajaran Process Oriented Guided Inquiry Learning (POGIL). Penelitian ini merupakan penelitian deskriptif kuantitatif. Subjek penelitian ini adalah mahasiswa Program Studi Tadris Matematika (TMA) STAIN Gajah Putih Takengon semester V sebanyak 67 orang. Instrumen dalam penelitian ini adalah lembar observasi dan angket. Lembar observasi digunakan untuk mengamati aktivitas dosen dan mahasiswa selama perkuliahan berlangsung, serta angket diberikan kepada mahasiswa untuk melihat peningkatan disposisi matematika dan Selfconfidence. Pemberian angket disposisi matematika dan self-confidence dilakukan sebelum dan setelah diberikan perlakuan menggunakan model Process Oriented Guided Inquiry Learning (POGIL). Berdasarkan hasil penelitian dapat disimpulkan bahwa model Process Oriented Guided Inquiry Learning (POGIL) dapat meningkatkan disposisi matematika dan self-confidence mahasiswa. Nilai ratarata disposisi matematika mahasiswa sebelum perlakuan adalah 64,10, sedangkan setelah diberi perlakuan menjadi 76,91. Nilai rata-rata Self-confidence rata-rata sebelum perlakuan adalah 49,61, setelah perlakuan meningkat menjadi 59,79.
\end{abstract}

Kata Kunci: POGIL, disposisi matematika, self-confidence

\section{Model of process oriented guided inquiry learning (POGIL): Improving mathematical disposition and self-confidence of students' tadris matematika}

\begin{abstract}
This study was aimed to know improvement of students' mathematical disposition and selfconfidence with applying model of Process Oriented Guided Inquiry Learning (POGIL). The method of this study was descriptive quantitative. The subjects were 50 students of Tadris Matematika (TMA) STAIN Gajah Putih Takengon, Nangroe Aceh Darussalam, Indonesia, in semester V. The instruments of this study were observation sheet and questionnaires. Observation sheet was using to observe activities of lecturer and students on learning process, while questionnaire was giving to students to know improvement of their mathematical disposition and self-confidence. The students filled the questionnaire before and after they were given a treatment. Based on the results of this study it could be concluded that model of Process Oriented Guided Inquiry Learning (POGIL) could improve students' mathematical disposition and self-confidence. The average score of students' mathematical disposition in pre-treatment was 64.10 and after treatment was 76.91. While, the average score of students' self-confidence in pre-treatment was 49.61 and after treatment was 59.79.
\end{abstract}

Keywords: POGIL, mathematical disposition, self-confidence

How to Cite: Rahmadhani, E. (2018). Model pembelajaran process oriented guided inquiry learning (POGIL): Peningkatan disposisi matematika dan self-confidence mahasiswa tadris matematika. Jurnal Riset Pendidikan Matematika, 5(2), 159-167. doi:https://doi.org/10.21831/jrpm.v0i0.20962

Permalink/DOI: https://doi.org/10.21831/jrpm.v0i0.20962 


\section{Jurnal Riset Pendidikan Matematika, 5 (2), 2018 - 160}

Elfi Rahmadhani

\section{PENDAHULUAN}

Pendidikan merupakan salah satu aspek penting dalam meningkatkan kualitas hidup seseorang. Melalui pendidikan, seseorang yang tidak tahu menjadi tahu. Pendidikan tidak hanya didapatkan dari sekolah, tapi juga bisa diperoleh dari kehidupan sehari-hari. Salah satu mata pelajaran yang berhubungan langsung dengan kehidupan sehari-hari adalah matematika. Matematika merupakan salah satu mata pelajaran yang diajarkan di setiap jenjang pendidikan, mulai dari sekolah dasar sampai perguruan tinggi. Dalam matematika siswa tidak hanya diberikan rumus saja, tetapi siswa juga dilatih untuk dapat menyelesaikan masalah yang berkaitan dengan kehidupan sehari-hari.

Berdasarkan observasi yang peneliti lakukan di kelas matematika, terlihat bahwa masih ada beberapa mahasiswa yang kurang percaya diri ketika pembelajaran matematika berlangsung. Mereka terlihat tidak percaya diri dengan jawabannya sendiri ketika diminta untuk menyelesaikan soal yang diberikan, dan mereka juga terlihat kurang gigih dalam menemukan konsep dari materi yang diberikan. Ketika mereka tidak paham dengan konsep dari materi yang diberikan, mereka tidak mau bertanya kepada dosen. Ada yang mampu menyelesaikan soal dengan baik tapi tidak mampu mengkomunikasikannya. Hal ini disebabkan karena kurangnya minat dan motivasi mahasiswa dalam belajar. Kondisi ini jika dibiarkan akan mengakibatkan mahasiswa semakin kesulitan dalam pembelajaran. Padahal mereka adalah mahasiswa jurusan pendidikan matematika yang diharapkan memiliki ketertarikan dan apresiasi yang tinggi terhadap matematika, agar mereka nantinya menjadi seorang guru yang profesional di bidangnya. Ketertarikan dan apresiasi yang tinggi terhadap matematika lebih dikenal sebagai disposisi matematika (National Council of Teachers of Mathematics, 1989).

Sumarmo (Lestari, \& Yudhanegara, 2015, p. 92) mengemukakan bahwa disposisi matematis adalah keinginan, kesadaran, kecenderungan dan dedikasi yang kuat pada diri siswa untuk berpikir dan berbuat secara matematis. Disposisi matematis adalah sikap positif siswa terhadap matematika yang mendorong mereka untuk memiliki minat dan rasa ingin tahu terhadap matematika, serta gigih dan ulet dalam menemukan solusi dari permasalahan matematika yang disajikan. Menurut Maxwell (2001), disposisi terdiri dari: (a) inclination (kecenderungan), yaitu bagaimana sikap sesorang terhadap tugas-tugas; (b) sensitivity (kepekaan), yaitu bagaimana kesiapan seseorang dalam menghadapi tugas; (c) ability (kemampuan), yaitu bagaimana seseorang fokus untuk menyelesaikan tugas secara lengkap; (d) enjoyment (kesenangan), yaitu bagaimana tingkah laku seseorang dalam menyelesaikan tugas.

Lebih lanjtu Polking (Syaban, 2008, p. 32) menyatakan bahwa disposisi matematika meliputi: (a) kepercayaan dalam menggunakan matematika untuk memecahkan permasalahan, untuk mengomunikasikan gagasan, dan untuk memberikan alasan; (b) fleksibilitas dalam menyelidiki gagasan matematis dan berusaha mencari metoda alternatif dalam memecahkan permasalahan; (c) tekun untuk mengerjakan tugas matematika; (d) mempunyai minat, keingintahuan (curiosity), dan daya temu dalam melakukan pekerjaan matematika; (d) kecenderungan untuk memonitor dan merefleksikan performance dan penalaran mereka sendiri; (e) menilai aplikasi matematika ke situasi lain yang timbul dalam matematika dan pengalaman sehari-hari; (f) penghargaan (appreciation) peran matematika dalam kultur dan nilai, baik matematika sebagai alat, maupun matematika sebagai bahasa.

Maxwell (2001, p. 171) menyatakan bahwa disposisi matematika siswa harus ditingkatkan, karena merupakan faktor utama dalam menentukan kesuksesan belajar siswa. Tanpa disposisi matematika yang baik, siswa akan kesulitan untuk mencapai kompetensi dan kecakapan matematika yang diinginkan (Purwasih \& Bernad, 2018, p. 45). Selain itu, siswa memerlukan disposisi matematika agar mereka mampu bertahan dalam menghadapi masalah matematika, mengambil tanggung jawab dalam proses pembelajaran matematika, dan mengembangkan kebiasaan kerja yang baik dalam aktivitas pembelajaran matematika (Sholikhah \& Hartono, 2015; Setyaningsih \& Widjajanti, 2015).

Selain disposisi matematika, selfconfidence atau percaya diri siswa juga harus ditingkatkan dalam pembelajaran matematika (Hilman \& Retnawati, 2015; Agustyaningrum \& Widjajanti, 2013). Percaya diri merupakan aspek kepribadian yang penting dalam diri seseorang, tanpa percaya diri maka akan banyak timbul masalah pada diri mereka. Self-confidence adalah suatu sikap yakin akan kemampuan diri sendiri dan memandang diri sendiri sebagai pribadi yang utuh dengan mengacu pada konsep diri. Menurut Fishbein dan Ajzen (Parson, Croft, \& Harrison, 2011, p. 53), "self-confidence is a belief", kepercayaan diri adalah sebuah keyakinan. Sementara menurut Scoenfeld (Hannula, Maijala, 
\& Pehkonen, 2004, p. 17), keyakinan adalah pemahaman dan perasaan individu yang membentuk cara bahwa konsep individu dan terlibat dalam perilaku matematika. Selain itu, kepercayaan diri juga dianggap sebagai keyakinan untuk melakukan sesuatu pada diri subjek sebagai karakteristik pribadi yang di dalamnya terdapat kemampuan diri, optimis, objektif, bertanggung jawab, rasional dan realistis (Ghufron \& Risnawita, 2010, p. 35).

Hamdan (2009, p. 7) telah meriview beberapa penelitian sebelumnya tentang selfconfidence dan menyimpulkan bahwa selfconfidence merupakan penilaian positif terhadap diri sendiri mengenai kemampuan yang ada dalam dirinya untuk menghadapi berbagai situasi dan tantangan serta kemampuan mental untuk mengurangi pengaruh negatif dari keragu-raguan yang mendorong individu untuk meraih keberhasilan atau kesuksesan tanpa tergantung kepada pihak lain dan bertanggung jawab atas keputusan yang telah ditetapkannya.

Menurut Lauster (Ghufron \& Risnawita, 2010, pp. 35-36), kepercayaan diri meliputi beberapa aspek. Pertama, keyakinan akan kemampuan diri. Keyakinan akan kemampuan diri adalah sikap positif seseorang tentang dirinya dan keyakinan akan kemampuan yang dimilikinya. Kedua, optimis yaitu sikap positif yang dimiliki seseorang yang selalu berpandangan baik dalam menghadapi segala hal yang berkaitan dengan diri dan kemampuannya. Ketiga, objektif yaitu seseorang yang memandang permasalahan sesuai dengan kebenaran yang semestinya, bukan menurut dirinya. Keempat, bertanggung jawab yaitu kesediaan seseorang untuk menanggung segala sesuatu yang telah menjadi konsekuensinya. Kelima, rasional dan realistis yaitu melakukan analisis terhadap suatu masalah, suatu hal, dan suatu kejadian dengan menggunakan pemikiran yang dapat diterima oleh akal dan sesuai dengan kenyataan.

Melihat pentingnya disposisi matematika dan self-confidence dimiliki oleh setiap peserta didik, baik siswa maupun mahasiswa, maka perlu dilakukan suatu usaha oleh pendidik untuk meningkatkan disposisi matematika dan selfconfidence mahasiswa tersebut. Salah satunya adalah dengan pemilihan model pembelajaran yang relevan dan dapat memfasilitasi peningkatan kemampuan disposisi matematika sekaligus kepercayaan diri mahasiswa. Salah satu model pembelajaran yang dapat digunakan untuk meningkatkan atau mengembangkan disposisi matematika dan self-confidence mahasiswa adalah model pembelajaran Process Oriented Guided Inquiry Learning (POGIL). Hanson (2006) menerangkan bahwa dalam metode Process Oriented Guided Inquiry Learning (POGIL) siswa belajar secara berkelompok dalam aktivitas yang dirancang untuk meningkatkan penguasaan isi dari mata pelajaran dan mengembangkan kemampuan dalam proses belajar, berpikir, menyelesaikan masalah, berkomunikasi, kerja kelompok, managemen dan evaluasi. Sementara Barthlow (2011) menyatakan bahwa aktivitas dalam Process Oriented Guided Inquiry Learning (POGIL) fokus pada konsep isi dan proses sains untuk mendorong pemahaman yang dalam terhadap materi serta mengembangkan kemampuan berpikir tingkat tinggi. Process Oriented Guided Inquiry Learning (POGIL) menekankan pada pembelajaran kooperatif, siswa bekerja dalam tim, mendesain kegiatan untuk membangun kemampuan kognitif (conceptual understanding), dan mengembangkan keterampilan selama proses pembelajaran seperti proses sains, keterampilan berfikir, pemecahan masalah (problem solving), keterampilan komunikasi, manajemen, membangun sikap sosial yang positif dan keterampilan assessment diri yang dapat mengembangkan pengetahuan metakognitif.

Process Oriented Guided Inquiry Learning (POGIL) adalah pembelajaran aktif dan berpusat pada siswa dan didasari oleh siklus belajar. Siklus belajar menyatakan bahwa pembelajaran terjadi dalam tiga tahap, yaitu: eksplorasi, penemuan konsep dan aplikasi (Atkin \& Karplus dalam Barthlow, 2011). Hal ini senada dengan Hanson (2006) yang menyatakan bahwa siklus pembelajaran dalam Process Oriented Guided Inquiry Learning (POGIL) terdiri atas tiga tahap yaitu: eksplorasi, penemuan konsep atau formasi, dan aplikasi. Dalam model Process Oriented Guided Inquiry Learning (POGIL), pendidik memiliki empat peran utama, yaitu sebagai pemimpin (leader), penilai (monitoring/assessor), fasilitator dan evaluator. Dalam tahap eksplorasi siswa akan menjawab berbagai macam pertanyaan untuk mengembangkan pemahaman terhadap suatu konsep. Pada tahap penemuan konsep, guru sebagai fasilitator pembelajaran memberikan bantuan kepada siswa untuk menemukan konsep. Konsep tidak diberikan secara eksplisit, namun guru mendorong dan memacu siswa untuk dapat membuat kesimpulan dan membuat prediksi. Dalam tahap aplikasi, siswa dipandu menggunakan pengetahuan baru yang telah diperolehnya untuk memecahkan masalah-masalah yang kompleks. Dalam tahap aplikasi siswa dihadapkan 
dengan soal-soal yang memiliki tingkatan tinggi yang membutuhkan analisis mendalam untuk dapat menjawabnya. Tahap akhir pembelajaran adalah evaluasi diri, siswa mengevaluasi performa belajarnya, apa yang telah diperoleh dan apa yang belum diperoleh untuk dapat meningkatkan kemampuannya pada kesempatan berikutnya. Evaluasi diri merupakan salah satu indikator berkembangnya kemampuan metakognisi siswa.

Dengan menggunakan model pembelajaran Process Oriented Guided Inquiry Learning (POGIL) ini, disposisi matematika dan selfconfidence siswa dapat ditingkatkan, karena pembelajaran lebih menekankan pada kerjasama tim, keterampilan berkomunikasi dan membangun sikap positif siswa. Dengan demikian, akan timbul sikap percaya diri, optimis, bertanggung jawab dan apresiasi siswa dalam pembelajaran. Hal ini sejalan dengan pendapat Hanson (2004) yang mengatakan bahwa tujuan model pembelajaran Process Oriented Guided Inquiry Learning (POGIL) diantaranya: (a) mengembangkan keterampilan proses pada area belajar (learning), berpikir (thinking), dan menyelesaikan masalah (problem solving); (b) membuat siswa berpartisipasi aktif dalam pembelajaran; (c) meningkatkan interaksi antar siswa dan interaksi antar guru dan siswa; (d) menumbuhkan sikap positif terhadap sains; (e) mengaitkan pembelajaran dengan teknologi informasi; (f) mengembangkan keterampilan komunikasi dan kinerja dalam kelompok

Untuk mengukur disposisi matematis siswa, indikator yang digunakan menurut Syaban (2008, p. 33) adalah sebagai berikut: (a) menunjukkan gairah/antusias dalam belajar matematika; (b) menunjukkan perhatian yang serius dalam belajar matematika; (c) menunjukkan kegigihan dalam menghadapi permasalahan; (d) menunjukkan rasa percaya diri dalam belajar dan menyelesaikan masalah; (e) menunjukkan rasa ingin tahu yang tinggi; (f) menunjukkan kemampuan untuk berbagi dengan orang lain.

Selain itu, indikator disposisi matematis menurut Lestari, \& Yudhanegara (2015, p. 92) yang dapat digunakan meliputi: (a) rasa percaya diri dalam menggunakan matematika, menyelesaikan masalah, memberi alasan dan mengkomunikasikan gagasan; (b) fleksibilitas dalam menyelidiki gagasan matematis dan berusaha mencari metode alternatif dalam menyelesaikan masalah; (c) tekun mengerjakan tugas matematika; (d) memiliki minat, rasa ingin tahu, dan daya temu dalam melakukan tugas matematika; (e) memonitor dan merefleksikan performance yang dilakukan; (f) menilai aplikasi matematika ke situasi lain dalam matematika dan pengalaman sehari-hari; (g) mengapresiasi peran matematika dalam kultur dan nilai matematika sebagai alat dan sebagai bahasa

Sementara itu, untuk mengukur selfconfidence seseorang menurut Lestari, \& Yudhanegara (2015, p. 95) dapat menggunakan indikator: (a) percaya pada kemampuan sendiri; (b) bertindak mandiri dalam mengambil keputusan; (c) memiliki konsep diri yang positif; dan (d) berani mengemukakan pendapat.

Berdasarkan hal tersebut, maka perlu dilakukan suatu penelitian untuk melihat peningkatan disposisi matematika dan self-confidence mahasiswa dengan menerapkan model Process Oriented Guided Inquiry Learning (POGIL). Dengan demikian tujuan penelitian adalah untuk mengetahui peningkatan disposisi matematika dan self-confidence mahasiswa dengan menerapkan model pembelajaran Process Oriented Guided Inquiry Learning (POGIL).

\section{METODE}

Penelitian ini merupakan penelitian kuantitatif dengan menggunakan pendekatan deskriptif, yang bertujuan untuk melihat peningkatan disposisi matematika dan self-confidence mahasiswa dengan pembelajaran menggunakan model Process Oriented Guided Inquiry Learning (POGIL).

Populasi pada penelitian ini adalah mahasiswa semester V Jurusan Tadris Matematika (TMA) Sekolah Tinggi Agama Islam Negri (STAIN) Gajah Putih Takengon, Provinsi Nangroe Aceh Darussalam yang terdaftar pada semester genap tahun akademik 2016/2017 yang terdiri dari dua kelas yaitu unit A sebanayak 33 mahasiswa dan unit B sebanyak 34 siswa. Sehingga jumlah subjek penelitian adalah 67 mahasiswa.

Instrumen yang digunakan untuk mengumpulkan data dalam penelitian ini adalah observasi dan angket. Observasi digunakan untuk melihat aktivitas dosen dan mahasiswa selama proses pembelajaran berlangsung, dan angket digunakan untuk melihat disposisi matematika dan self-confidence mahasiswa terhadap pembelajaran dengan model Process Oriented Guided Inquiry Learning (POGIL). Observasi dilakukan terhadap dosen dan mahasiswa, dimana observasi terhadap dosen digunakan untuk melihat bagaimana cara dosen mengajar dan observasi terhadap mahasiswa digunakan untuk melihat bagaimana aktivitas mahasiswa dalam belajar. Sementara itu, angket skala sikap disposisi matematika 
dan self-confidence diberikan kepada mahasiswa kelas sampel sebelum dan sesudah pembelajaran dilaksanakan. Skala yang digunakan pada angket ini adalah skala likert dengan empat pilihan jawaban yaitu Sangat Tidak Setuju (STS), Tidak Setuju (TS), Setuju (S), dan Sangat Setuju (SS). Angket disposisi matematika terdiri dari 26 butir pernyataan dengan indikator: (1) percaya diri dalam menyelesaikan masalah matematika, (2) berpikir fleksibel dalam mengeksplorasi ide-ide matematis dan mencoba metode alternatif dalam menyelesaikan masalah, (3) gigih dalam mengerjakan tugas matematika, (4) berminat, memiliki keingintahuan dan memiliki daya cipta dalam aktivitas bermatematika (5) mengapresiasikan peran matematis sebagai alat dan bahasa (apresiasi), dan (6) berbagi pendapat dengan orang lain (refleksif). Sementara itu, angket self-confidence terdiri dari 20 butir pernyataan yang harus direspon oleh mahasiswa dengan indikator: (1) optimis, (2) keyakinan kemampuan diri, dan (3) bertanggung jawab.

Angket disposisi matematika dan selfconfidence diujicobakan pada kelas lain sebelum diberikan kepada kelas sampel untuk mengetahui tingkat keterbacaan bahasa dan untuk memperoleh gambaran apakah pernyataan-pernyataan yang diberikan dapat dipahami oleh mahasiswa atau tidak. Dari hasil ujicoba, ternyata diperoleh gambaran bahwa semua pernyataan yang diberikan dapat dipahami dengan baik oleh mahasiswa.

Data kualitatif dalam penelitian ini diperoleh dari hasil lembar observasi aktivitas dosen dan mahasiswa selama menggunakan model pembelajaran Process Oriented Guided Inquiry Learning (POGIL). Pengamatan yang dilakukan selama pembelajaran dicatat dalam lembar observasi dan data disajikan dalam bentuk persentase aktivitas mahasiswa dalam setiap pertemuan. Persentase ini kemudian diklasifikasikan menjadi sangat kurang, kurang, cukup, baik, dan sangat baik.

Data tentang disposisi matematika dan self-confidence mahasiswa diperoleh dari angket yang diberikan. Untuk angket disposisi matematika terdiri dari 26 pernyataan dengan skor berada pada rentang 26 sampai dengan 104, sedangkan angket self-confidence terdiri dari 20 pernyataan dengan skor berada pada rentang 20 sampai dengan 80. Untuk menentukan hasil pengukuran, data ordinal yang didapatkan ditransformasi menjadi data interval dengan menggunakan Metode Successive Interval (MSI) dengan klasifikasi berdasarkan rata-rata ideal (Mi) dan standar deviasi ideal ( $\mathrm{Si}$ ) dengan skala empat. Selanjutnya dihitung persentasenya untuk masing-masing kategori, yaitu sangat tinggi, tinggi, sedang, rendah dan sangat rendah.

\section{HASIL DAN PEMBAHASAN}

\section{Hasil Observasi}

Lembar observasi digunakan untuk melihat aktivitas dosen dan mahasiswa ketika menerapkan model pembelajaran Process Oriented Guided Inquiry Learning (POGIL). Observasi terhadap dosen digunakan untuk melihat bagaimana cara dosen mengajar dengan menggunakan model pembelajaran Process Oriented Guided Inquiry Learning (POGIL) dan observasi terhadap mahasiswa digunakan untuk melihat bagaimana aktivitas mahasiswa dalam belajar dengan menggunakan model pembelajaran Process Oriented Guided Inquiry Learning (POGIL). Dari hasil pengolahan data lembar observasi terlihat bahwa dosen telah menerapkan dengan baik setiap langkah-langkah dalam metode pembelajaran Process Oriented Guided Inquiry Learning (POGIL). Terlihat dari nilai rata-rata observasi aktivitas dosen yang diperoleh adalah 85\% selama pertemuan dengan kategori baik. Sementara selama pengamatan terhadap mahasiswa dilakukan dalam penelitian terlihat bahwa terjadi peningkatan aktivitas mahasiswa dari pertemuan pertama sampai pertemuan terakhir ketika diberikan model pembelajaran Process Oriented Guided Inquiry Learning (POGIL). Nilai rata-rata observasi terhadap mahasiswa adalah $83,7 \%$. Terlihat bahwa mahasiswa aktif selama pembelajaran berlangsung dan disposisi matematika serta self-confidence mereka meningkat selama pembelajaran.

\section{Hasil Angket}

Pada penelitian ini, selain dengan lembar observasi data didapatkan dari angket, yang digunakan untuk melihat disposisi matematika dan self-confidence mahasiswa. Angket disposisi matematika terdiri dari 26 pernyataan dengan skor berada pada rentang 26 sampai dengan 104, sedangkan angket Self-confidence terdiri dari 20 pernyataan dengan skor berada pada rentang 20 sampai dengan 80 . Kedua angket ini diberikan untuk melihat peningkatan yang terjadi akibat perlakuan yang diberikan. Kisi-kisi angket disposisi matematika dan self-confidence dari salah satu indikator yang digunakan dalam penelitian dapat dilihat pada Tabel 1. 
Jurnal Riset Pendidikan Matematika, 5 (2), 2018 - 164

Elfi Rahmadhani

Tabel 1. Kisi-Kisi Angket Disposisi Matematika dan Self-confidence

\begin{tabular}{|c|c|c|c|}
\hline Angket & Indikator & Contoh Pernyataan & $\begin{array}{c}\text { Jenis } \\
\text { Pernyataan }\end{array}$ \\
\hline \multirow[t]{4}{*}{$\begin{array}{l}\text { Disposisi } \\
\text { Matematika }\end{array}$} & \multirow[t]{2}{*}{ Percaya diri } & $\begin{array}{l}\text { 1. Saya yakin dapat memperoleh nilai yang baik dalam } \\
\text { matematika }\end{array}$ & + \\
\hline & & $\begin{array}{l}\text { 2. Saya selalu ragu-ragu jika jawaban saya berbeda } \\
\text { dari teman }\end{array}$ & - \\
\hline & \multirow[t]{2}{*}{ Keingintahuan } & $\begin{array}{l}\text { 1. Saya mencari tambahan materi matematika pada } \\
\text { sumber lain }\end{array}$ & + \\
\hline & & $\begin{array}{l}\text { 2. Saya tidak membaca buku pelajaran matematika di } \\
\text { rumah }\end{array}$ & - \\
\hline \multirow[t]{4}{*}{ Self-confidence } & \multirow[t]{2}{*}{ Optimis } & $\begin{array}{l}\text { 1. Saya merasa tertantang untuk mempresentasikan } \\
\text { hasil pekerjaan di depan kelas }\end{array}$ & + \\
\hline & & $\begin{array}{l}\text { 2. Saya merasa cemas dalam menghadapi ulangan } \\
\text { matematika }\end{array}$ & - \\
\hline & \multirow[t]{2}{*}{$\begin{array}{l}\text { Bertanggung } \\
\text { Jawab }\end{array}$} & $\begin{array}{l}\text { 1. Saya berusaha dengan sungguh-sungguh dalam } \\
\text { menyelesaikan pekerjaan rumah }\end{array}$ & + \\
\hline & & $\begin{array}{l}\text { 2. Saya menghindar untuk mewakili kelompok } \\
\text { presentasi di depan kelas }\end{array}$ & - \\
\hline
\end{tabular}

Tabel 2. Skor Disposisi Matematika dan Self-confidence

\begin{tabular}{lcccc}
\hline \multirow{2}{*}{ Ukuran Statistik } & \multicolumn{2}{c}{ Disposisi Matematika } & \multicolumn{2}{c}{ Self-confidence } \\
\cline { 2 - 5 } & Sebelum Perlakuan & Setelah Perlakuan & Sebelum Perlakuan & Setelah Perlakuan \\
\hline Banyak mahasiswa & 67 & 67 & 67 & 67 \\
Rata-rata & 64,10 & 76,91 & 49,61 & 59,79 \\
\hline
\end{tabular}

Tabel 3. Distribusi Frekuensi dan Persentase Disposisi Matematika

\begin{tabular}{llcccc}
\hline \multirow{2}{*}{ Interval skor } & \multicolumn{2}{c}{ Kategori } & \multicolumn{2}{c}{ Sebelum Perlakuan } & \multicolumn{2}{c}{ Setelah Perlakuan } \\
\cline { 3 - 5 } & & $F$ & $\%$ & $F$ & $\%$ \\
\hline Skor $>90$ & Sangat tinggi & 0 & 0 & 2 & 2,99 \\
$80<$ skor $\leq 90$ & Tinggi & 0 & 0 & 19 & 28,36 \\
$70<$ skor $\leq 80$ & Sedang & 10 & 14,93 & 36 & 53,73 \\
$60<$ skor $\leq 70$ & Rendah & 38 & 56,72 & 8 & 11,94 \\
Skor $\leq 60$ & Sangat rendah & 19 & 28,36 & 2 & 2,99 \\
\hline
\end{tabular}

Tabel 4. Distribusi Frekuensi dan Persentase Self-confidence

\begin{tabular}{llcccc}
\hline \multirow{2}{*}{ Interval skor } & \multicolumn{2}{c}{ Kategori } & \multicolumn{2}{c}{ Sebelum Perlakuan } & \multicolumn{2}{c}{ Setelah Perlakuan } \\
\cline { 3 - 5 } & & $F$ & $\%$ & $F$ & $\%$ \\
\hline Skor $>70$ & Sangat tinggi & 0 & 0 & 4 & 5,97 \\
$60<$ skor $\leq 70$ & Tinggi & 3 & 4,48 & 28 & 41,79 \\
$50<$ skor $\leq 60$ & Sedang & 26 & 38,81 & 30 & 44,78 \\
$40<$ skor $\leq 50$ & Rendah & 34 & 50,75 & 5 & 7,46 \\
Skor $\leq 40$ & Sangat rendah & 4 & 5,97 & 0 & 0 \\
\hline
\end{tabular}

Angket disposisi matematika dan selfconfidence ini diberikan kepada mahasiswa sebelum dan setelah diberikan perlakuan berupa model pembelajaran Process Oriented Guided Inquiry Learning (POGIL). Setiap indikator memiliki pernyataan positif dan negatif yang harus direspon oleh mahasiswa. Setelah angket diberikan, maka data yang diperoleh diolah untuk melihat peningkatan yang terjadi pada disposisi matematika dan self-confidence mahasiswa. Data hasil pengukuran disposisi matematika dan selfconfidence mahasiswa dapat dilihat pada Tabel 2.
Berdasarkan Tabel 2, terlihat bahwa dari 67 mahasiswa yang diteliti, ternyata rata-rata skor disposisi matematika mereka sebelum perlakuan adalah 64,10 , sedangkan setelah diberi perlakuan dengan menggunakan model pembelajaran Process Oriented Guided Inquiry Learning (POGIL) terjadi peningkatan rata-rata, sehingga skornya menjadi 76,91. Sementara itu, untuk selfconfidence dari 67 mahasiswa yang diteliti, ternyata rata-rata skor self-confidence mereka sebelum perlakuan adalah 49,61, sedangkan setelah diberi perlakuan dengan menggunakan model pembelajaran Process Oriented Guided Inquiry 
Learning (POGIL) terjadi peningkatan rata-rata yaitu menjadi 59,79. Hal ini menunjukkan bahwa secara deskriptif pemberian model pembelajaran Process Oriented Guided Inquiry Learning (POGIL) mempengaruhi disposisi matematika dan self-confidence mahasiswa Jurusan Tadris Matematika (TMA).

Sementara itu, untuk melihat kategori disposisi matematika dan self-confidence setiap mahasiswa dapat dilakukan dengan menghitung frekuensi dan persentase banyaknya mahasiswa yang dilihat berdasarkan rentang skor yang telah ditentukan. Distribusi frekuensi dan persentase disposisi matematika mahasiswa sebelum dan setelah diberikan perlakuan menggunakan model pembelajaran Process Oriented Guided Inquiry Learning (POGIL) dapat dilihat pada Tabel 3.

Dari Tabel 3 terlihat bahwa sebelum perlakuan tidak ada mahasiswa yang berada pada kategori sangat tinggi dan tinggi untuk disposisi matematika. Tapi setelah diberikan model pembelajaran Process Oriented Guided Inquiry Learning (POGIL), terdapat 2 orang mahasiswa atau 2,99\% mahasiswa berada pada kategori disposisi matematika sangat tinggi dan 19 orang mahasiswa atau $28,36 \%$ mahasiswa berada pada kategori disposisi matematika tinggi. Untuk kategori sedang, rendah dan sangat rendah juga terjadi peningkatan disposisi matematika. Terlihat dari kategori sangat rendah yang pada awalnya ada 19 orang mahasiswa atau $28,36 \%$ mahasiswa, setelah diberi perlakuan berkurang menjadi 2 orang mahasiswa saja atau $2,99 \%$. Hal ini juga terlihat pada kategori rendah, sebelum perlakuan ada 38 orang mahasiswa atau $56,72 \%$ mahasiswa, setelah diberi perlakuan berkurang menjadi 8 orang mahasiswa saja atau $11,94 \%$. Untuk kategori sedang terjadi peningkatan jumlah mahasiswa, sebelum perlakuan ada 10 orang mahasiswa atau $14,93 \%$ mahasiswa, setelah diberi perlakuan meningkat menjadi 36 orang mahasiswa atau $53,73 \%$.

Sedangkan distribusi frekuensi dan persentase self-confidence mahasiswa sebelum dan setelah diberikan perlakuan menggunakan model pembelajaran Process Oriented Guided Inquiry Learning (POGIL) dapat dilihat pada Tabel 4.

Dari Tabel 4 terlihat bahwa sebelum perlakuan tidak ada mahasiswa yang berada pada kategori sangat tinggi untuk self-confidence. Tapi setelah diberikan model pembelajaran Process Oriented Guided Inquiry Learning (POGIL), terdapat 4 orang mahasiswa atau 5,97\% mahasiswa berada pada kategori self-confidence sangat tinggi. Untuk kategori tinggi, sedang, rendah dan sangat rendah juga terjadi peningkatan selfconfidence. Terlihat dari kategori tinggi sebelum diberi perlakuan terdapat 3 orang mahasiswa atau $4,48 \%$ mahasiswa dan setelah diberi perlakuan meningkat menjadi 28 orang atau $41,79 \%$ mahasiswa, kategori sedang terdapat 26 mahasiswa atau $38,81 \%$ sebelum perlakuan dan 30 orang atau $44,78 \%$ mahasiswa setelah perlakuan. Pada kategori rendah sebelum perlakuan terdapat 34 orang mahasiswa atau 50,75\% mahasiswa meningkat menjadi 5 orang atau $7,46 \%$ mahasiswa setelah perlakuan dan kategori sangat rendah yang pada awalnya ada 4 orang mahasiswa atau 5,97\% mahasiswa, setelah diberi perlakuan tidak ada lagi mahasiswa yang berada pada kategori sangat rendah.

Berdasarkan indikator, hasil peningkatan disposisi matematika mahasiswa yang diberikan model pembelajaran Process Oriented Guided Inquiry Learning (POGIL) dapat dilihat pada Tabel 5.

Tabel 5. Peningkatan Disposisi Matematika Berdasarkan Indikator

\begin{tabular}{lccc}
\hline \multicolumn{1}{c}{ Indikator } & $\begin{array}{c}\text { Sebelum } \\
\text { Perlakuan }\end{array}$ & $\begin{array}{c}\text { Setelah } \\
\text { Perlakuan }\end{array}$ & N-Gain \\
\hline Percaya Diri & 12,24 & 15,04 & 0,22 \\
Fleksibel & 9,78 & 11,64 & 0,09 \\
Gigih dan & 9,96 & 11,70 & 0,08 \\
Tekun & & & \\
Keingintahuan & 12,13 & 14,78 & 0,18 \\
Apresiasi & 9,99 & 11,78 & 0,02 \\
Refleksif & 10,01 & 11,97 & 0,05 \\
\hline
\end{tabular}

Dari Tabel 5 dapat dilihat bahwa terjadi peningkatan untuk setiap indikator disposisi matematika setelah diberikan perlakuan menggunakan model pembelajaran Process Oriented Guided Inquiry Learning (POGIL). Rata-rata NGain disposisi matematika untuk indikator percaya diri adalah 0,22 , indikator fleksibel memiliki rata-rata $\mathrm{N}-$ Gain 0,09 , indikator gigih dan tekun sebesar 0,08 , indikator keingintahuan memiliki rata-rata $\mathrm{N}$-Gain sebesar 0,18 , indikator apresiasi dengan rata-rata $\mathrm{N}-$ Gain sebesar 0,02 dan indikator disposisi matematika refleksif memiliki rata-rata N-Gain sebesar 0,05. Peningkatan disposisi matematika ini dapat mengakibatkan aktivitas dan hasil belajar mahasiswa juga meningkat. Hal ini sesuai dengan yang diungkapkan oleh teori Schunk (Bandura, 1995, p. 209), bahwa kepercayaan diri dapat mempengaruhi aktivitas belajar dan prestasi akademik siswa. Meningkatnya disposisi matematika mahasiswa dikarenakan dosen memberikan kesempatan yang luas agar mahasiswa aktif dalam pembel- 
ajaran, dan dosen selalu mengaitkan konsep pembelajaran dengan teknologi informasi yang luas. Hal ini sesuai dengan pendapat Hanson (2004) yang mengatakan bahwa tujuan model pembelajaran Process Oriented Guided Inquiry Learning (POGIL) salah satunya adalah membuat siswa berpartisipasi aktif dalam pembelajaran, meningkatkan interaksi antar siswa dan interaksi antar guru dan siswa serta mengaitkan pembelajaran dengan teknologi informasi.

Hasil peningkatan Self-confidence mahasiswa yang diberikan model pembelajaran Process Oriented Guided Inquiry Learning (POGIL) berdasarkan indikator dapat dilihat pada Tabel 6.

Tabel 6. Peningkatan Self-Confidence Berdasarkan Indikator

\begin{tabular}{|c|c|c|c|}
\hline Indikator & $\begin{array}{l}\text { Sebelum } \\
\text { Perlakuan }\end{array}$ & $\begin{array}{c}\text { Setelah } \\
\text { Perlakuan }\end{array}$ & $\begin{array}{l}\mathrm{N}- \\
\text { Gain }\end{array}$ \\
\hline Optimis & 17,10 & 20,69 & 0,27 \\
\hline $\begin{array}{l}\text { Keyakinan } \\
\text { kemampuan diri }\end{array}$ & 17,78 & 20,82 & 0,23 \\
\hline $\begin{array}{l}\text { Bertanggung } \\
\text { jawab }\end{array}$ & 14,73 & 18,28 & 0,23 \\
\hline
\end{tabular}

Dari Tabel 6 dapat dilihat bahwa terjadi peningkatan untuk setiap indikator self-confidence setelah diberikan perlakuan menggunakan model pembelajaran Process Oriented Guided Inquiry Learning (POGIL). Rata-rata N-Gain self-confidence untuk indikator optimis adalah 0,27 , sedangkan indikator keyakinan kemampuan diri dan bertanggung jawab memiliki rata-rata $\mathrm{N}$ Gain sebesar 0,23. Hal ini menunjukkan bahwa model pembelajaran Process Oriented Guided Inquiry Learning (POGIL) mempengaruhi dan dapat meningkatkan disposisi matematika dan self-confidence mahasiswa. Hal ini sesuai dengan pendapat Hanson (2006) bahwa model pembelajaran Process Oriented Guided Inquiry Learning (POGIL) memiliki kelebihan, yaitu: (1) dapat mengembangkan pemahaman, pertanyaan untuk memancing berfikir kritis dan analitik, penyelesaian masalah, melaporkan hasil pengamatan, metakognitif dan tanggung jawab individu, (2) mampu bekerja sama dengan siswa lain untuk memahami konsep dan menyelesaikan masalah sehingga bonding antar siswa menjadi lebih kuat, serta (3) siswa mampu merefleksikan apa yang telah dipelajari dan meningkatkannya.

Dengan meningkatnya disposisi matematika dan self-confidence mahasiswa, maka hasil belajar merekapun akan meningkat, karena ketika mereka percaya pada kemampuan mereka sendiri, optimis dan bertanggung jawab dalam menghadapi setiap masalah yang diberikan, maka hasil belajar mereka akan menjadi lebih baik, karena kepercayan diri merupakan sifat yang melekat pada diri seseorang. Sesuai yang diungkapkan oleh Syam dan Amri (2017, p.1 00) bahwa kepercayaan diri berpengaruh terhadap hasil belajar mahasiswa, karena kepercayaan diri merupakan salah satu aspek kepribadian yang berupa keyakinan dan kemampuan diri seseorang sehingga tidak terpengaruh oleh orang lain dan dapat bertindak sesuai kehendak, gembira, optimis, cukup toleran dan bertanggung jawab.

\section{SIMPULAN}

Berdasarkan hasil penelitian dan pembahasan yang telah dikemukakan sebelumnya, diperoleh kesimpulan bahwa disposisi matematika dan self-confidence mahasiswa meningkat setelah memperoleh perlakuan dengan menggunakan model pembelajaran Process Oriented Guided Inquiry Learning (POGIL). Rata-rata hasil skor disposisi matematika sebelum perlakuan adalah 64,10 , sedangkan setelah diberi perlakuan menjadi 76,91. Sementara itu, untuk selfconfidence rata-rata skor mereka sebelum perlakuan adalah 49,61, sedangkan setelah diberi perlakuan dengan menggunakan model pembelajaran POGIL terjadi peningkatan rata-rata dan skornya menjadi 59,79. Peningkatan juga dapat dilihat dari persentase jumlah mahasiswa berdasarkan kategori dan indikator disposisi matematika dan Self-confidence untuk setiap mahasiswa. Rata-rata N-Gain disposisi matematika untuk indikator percaya diri adalah 0,22 , indikator fleksibel memiliki rata-rata N-Gain 0,09, indikator gigih dan tekun sebesar 0,08 , indikator keingintahuan memiliki rata-rata $\mathrm{N}-G a i n$ sebesar 0,18 , indikator apresiasi dengan rata-rata $\mathrm{N}$-Gain sebesar 0,02 dan indikator disposisi matematika refleksif memiliki rata-rata N-Gain sebesar 0,05. Sedangkan rata-rata N-Gain self-confidence untuk indikator optimis adalah 0,27, sedangkan indikator keyakinan kemampuan diri dan bertanggung jawab memiliki rata-rata $\mathrm{N}$-Gain sebesar 0,23 .

\section{DAFTAR PUSTAKA}

Agustyaningrum, N., \& Widjajanti, D. (2013). Pengaruh pendekatan CTL dengan setting kooperatif tipe kancing gemerincing terhadap kemampuan komunikasi matematis, kepercayaan diri, dan prestasi belajar matematika siswa SMP. Pythagoras: Jurnal Pendidikan Matematika, $\quad 8(2), \quad$ 171-180. doi:https://doi.org/10.21831/pg.v8i2.8946 
Bandura, A. (1995). Self-efficacy in changing societies. Cambridge, UK: Cambridge University Press

Barthlow, M. J. (2011). The Effectiveness of process guided inquiry learning to reduce alternate conception in secondary chemistry. Disertasi. Lynchburg: Liberty University.

Ghufron, M. N., \& Risnawita, R. (2010). Teoriteori psikologi. Yogyakarta: Ar-Ruzz Media.

Hamdan, H. (2009). Hubungan antara kepercayaan diri dengan motivasi berprestasi pada siswa SMUN 1 Setu Bekasi. Skripsi. Jakarta: Fakultas Psikologi Universitas Gunadarma. .

Hannula, M. S., Maijala, M., \& Pehkonen, E. (2004). Development of understanding self-confidence in mathematics; Grades 58. Proceedings of the $28^{\text {th }}$ Conference of the International Group for the Psychology of Mathematics Education, 3, pp 17-24.

Hanson, D. M. (2004). Process-oriented guided inquiry learning process: The missing element. What Works, What Matters, What Lasts, 4, 2-13. Retrieved from http://www.pkal.org/open.cfm?d_id=363

Hanson, D. M. (2006). Instructor's guide to process-oriented guided-inquiry learning. Lisle, IL: Pacific Crest.

Hilman, H., \& Retnawati, H. (2015). Pengembangan perangkat pembelajaran matematika SMP dengan metode inkuiri pada persamaan dan pertidaksamaan linear satu variabel. Jurnal Riset Pendidikan Matematika, 2(1), 40-50. doi:https://doi.org/10.21831/jrpm.v2i1.71 49

Lestari, K. E., \& Yudhanegara, M. R. (2015). Penelitian pendidikan matematika. Bandung: Refika Aditama

Maxwell, K. (2001). Positive learning dispositions in mathematics. ACE Papers, 11, 30-39.
National Council of Teachers of Mathematics. (1989). Profesional Standard For Teaching Mathematics. Reston, VA: Author.

Parson, S., Croft, T. \& Harrison, M. (2011). Engineering students self-confidence in mathematics mapped onto Bandura's selfefficacy. Engineering Education, 6(1), 5261.

Purwasih, R., \& Bernad, M. (2018). Pembelajaran diskursus multi representasi terhadap peningkatan kemampuan komunikasi dan disposisi matematis mahasiswa. Jurnal Riset Pendidikan Matematika, 5(1), 43-52. doi:http://dx.doi.org/10.21831/jrpm.v5i1. 13589

Setyaningsih, E., \& Widjajanti, D. (2015). Keefektifan pendekatan problem posing ditinjau dari prestasi belajar, kemampuan koneksi matematis, dan disposisi matematis. Pythagoras: Jurnal Pendidikan Matematika, 10(1), 28-37. doi:https://doi.org/10.21831/pg.v10i1.910 0

Sholikhah, M., \& Hartono, H. (2015). Perbandingan keefektifan antara problembased learning setting numbered head together dan setting jigsaw. Jurnal Riset Pendidikan Matematika, 2(1), 63 - 77. doi:https://doi.org/10.21831/jrpm.v2i1.71 51

Syaban, M. (2008). Menumbuhkan daya dan disposisi siswa SMA melalui pembelajaran investigasi. Disertasi, Universitas Pendidikan Indonesia, Bandung.

Syam, A., \& Amri, A. (2017). Pengaruh kepercayaan diri (self-confidence) berbasis kaderisasi IMM terhadap prestasi belajar mahasiswa (Studi kasus di Program Studi Pendidikan Biologi Fakultas Keguruan dan Ilmu Pendidikan Universitas Muhammadiyah Parepare). Jurnal Biotek, $5(1)$, 87-102. doi:https://doi.org/10.24252/jb.v5i1.3448 